\title{
SOVEREIGNTY, THE SUCCESSOR STATE, AND UNIVERSAL HUMAN RIGHTS: HISTORY AND THE INTERNATIONAL STRUCTURING OF ACEHNESE NATIONALISM'
}

Edward Aspinall

Most definitions of the nation emphasize notions like common sentiment, community, or collective identity. In Benedict Anderson's famous phrase, the nation is an "imagined political community," one that is "always conceived as a deep, historical comradeship." 2 Anthony Smith defines the nation as "a named human population sharing an historic territory, common myths and historical memories, a mass, public culture, a common economy and common legal rights and duties for all members." $\mathrm{He}$ equates his conception with "a cultural and political bond, uniting in a single community all who share an historic culture and homeland." 3

\footnotetext{
${ }^{1}$ I am thankful for helpful comments on an earlier draft of this article by the late Herbert Feith, Aleksandar Pavkovic', Gregory Acciaioli, James Siegel, Marcus Mietzner, and Sidney Jones. Any errors remain my responsibility.

This article will be incorporated in a volume to be edited by Vivienne Wee, tentatively entitled Political Fault-lines in Southeast Asia: Movements for Alternative Sovereignty in Nation-States, to be published by Routledge.

${ }^{2}$ Benedict Anderson, Imagined Communities: Reflections on the Origins and Spread of Nationalism, 2nd ed. (London: Verso, 1991), pp. 5, 7.

${ }^{3}$ Anthony D. Smith, National Identity (Reno: University of Nevada Press, 1991) pp. 14-15.
} 
In its very early usage, the term "nation" was not linked to political control over territory. ${ }^{4}$ This changed over time, especially during the nineteenth century, so that nationalism became, according to Ernest Gellner, "primarily a principle which holds that the political and national unit should be congruent." 5 The chief aim of a modern nationalist movement, therefore, and what distinguishes such a movement from one representing some other kind of identity group, is that it aims for a state of its own. ${ }^{6}$ This is the case both for national groups which imagine themselves as occupying the entire territory of an existing internationally recognized political unit (as with most anti-colonial nationalisms) and for secessionist nationalist groups which seek to break away from larger states. At the point which nationalism aspires for statehood, it steps from the realm of imagination and collective identity into the domain of the international system of states. Each nationalist movement is required to enter into dialogue with that system and stake a claim for equal representation within it.

A nationalist movement therefore needs to do more than assert its own sense of separate collective identity. Collective identity, after all, is possessed by all manner of sub-national minority groups. In the international system, the currency is not bonds of solidarity, sentiment, and community, but sovereignty, a concept which is at least as old as nationalism. Sovereign equality of all states, within which is embodied the principle of the inviolability and territorial integrity of each state, remains the bedrock of the international system. In order to gain rightful entry into the international system, each nationalist movement must therefore make a case for claiming sovereignty of its own. The dominant means by which such movements have done so over the last century has been by relying on the doctrine of self-determination, which, especially since the high period of decolonization after World War II, has been a core constitutive principle of the international system.

Since the mid-1980s, however, observers have drawn attention to the ways by which the system of nation-states, founded on the concept of sovereignty, has been challenged and undermined by the many processes collectively known as globalization. Flows of capital, information, and labor across national borders increasingly confound attempts at regulation by national governments, while state authorities have transferred responsibilities upward to a range of international or supranational bodies. New forms of global political, social, and civic organization have emerged, which no longer take single nation-states as their reference points. New global norms, such as those associated with the doctrine of universal human rights, present themselves as competitors to the classical doctrine of sovereignty, explicitly challenging the nationstate's claim to be the source of supreme political authority. Even if state sovereignty remains a basic organizing principle of the international system, many authors argue that the vague outlines of an historically novel global order are now apparent.?

\footnotetext{
${ }^{4}$ Liah Greenfield, Nationalism: Five Roads to Modernity (Cambridge, MA and London: Harvard University Press, 1992), pp. 4-8.

5 Ernest Gellner, Nations and Nationalism (Oxford: Blackwell, 1983), p. 1.

6 This is not to deny that some recent movements which call themselves nationalist and claim forms of sovereignty (such as some movements of indigenous peoples in North America and Australasia) do not aspire to independent territorial states.

7 See for example, Michael Hardt and Antonio Negri, Empire (Cambridge, MA and London: Harvard University Press, 2000).
} 
The purpose of this article is to examine how this evolving international context has molded the nationalism of the secessionist movement in Aceh. It is argued that the nationalist claims made, and the national identity promoted, by the Acehnese independence movement have to a large degree been shaped by the movement's interaction with the international system. This is because each nation, including the putative Acehnese one, is not only constituted "internally" (by constructing a shared sense of identity among the participants in the nation), but also "externally" (by asserting the nation-state's legitimate participation in the international system). Virtually every element in the Acehnese nationalist appeal plays a dual role and is directed at both an international and a domestic audience. In particular, this essay will demonstrate that nationalist constructions of history, usually depicted in theoretical literature on nationalism as having primarily domestic concerns (the inculcation of national pride in the population, the establishment of national social cohesion, legitimation of national institutions, and the like) can also be profoundly influenced by interaction with the international system. The Acehnese nationalist interpretation of history has been especially influenced by the attempt to fashion Aceh's claim to independence within the dominant international idiom of sovereignty and selfdetermination. In more recent years, processes associated with globalization have also influenced Acehnese nationalism. Strengthening universal human rights discourse in the international arena has partially changed the way in which independence demands are formulated. This discourse, combined with the influence of an emergent global civil society, has also produced the first hints of a post-nationalist imagination of politics in Aceh.

\section{Origins of Acehnese Nationalism}

Acehnese nationalism, at least in its modern form, is a relatively recent historical phenomenon, and one that has emerged primarily as a reaction to the activities of the Indonesian state. It is true that the sultanate of Aceh was a significant force in the Malacca straits for several centuries, especially during its high point under Sultan Iskandar Muda in the early seventeenth century. Although much diminished by the mid-nineteenth century, the sultanate was once again a considerable power, in large part due to the booming pepper trade. Even at this point, however, the sultanate was a loosely organized polity, which did not constitute a territorial nation-state in the modern sense. ${ }^{8}$ Nevertheless, the full-scale assault launched by the Dutch in 1873 provoked strong resistance and resulted in one of the most protracted and costly wars of colonial expansion in Southeast Asia. In 1903, Aceh's last Sultan, Muhammad Daud, surrendered, and by 1910 the Dutch had more or less consolidated their control over the territory. Violent but sporadic resistance persisted until the end of the Dutch period. During the 1945-49 Indonesian independence struggle, the vast bulk of the anti-colonial Acehnese religious and political leadership identified with the Indonesian Republican cause, and no significant voices were raised in the territory in favor of Acehnese independence. Even before the revolution, in the 1930s and early 1940s, when there was an upsurge of Islamic reformism and Acehnese revivalism in the territory, "the idea of Acehnese revival [did not] preclude, as such, notions of

\footnotetext{
${ }^{8}$ On the internal organization of the sultanate, see James T. Siegel, The Rope of God (Berkeley and Los Angeles: University of California Press, 1969), pp. 35-47.
} 
overarching Indonesian unity."9 This makes the Acehnese experience quite distinct from, for example, the experiences of Bangsamoro and Karen nationalists, whose objections to union with the Philippines and Burma were raised either prior to, or shortly after, independence.

Nevertheless, once independence was attained, it proved difficult to maintain the unified vision of an Indonesian nation which had been achieved during the anticolonial struggle. New tensions arose partly because Indonesian national identity had been formed in opposition to Dutch rule, and once alien overlordship was removed, conflicting ideas of how the nation should be constituted came into increasingly open competition. This was most evident in the Indonesia-wide conflict, particularly acute in Aceh, over whether Islam or Pancasila should constitute the ideological basis of the new state. Tensions also flowed from the competing political logics of nation- and state-building. Immediately following the transfer of sovereignty, the leaders of Indonesia's national government moved to assert their authority throughout the archipelago, embarking upon a program of state-building and partly drawing upon the apparatus and personnel of the late Dutch East Indies colonial beamtenstaat. Early steps toward centralization of government control, such as Aceh's incorporation within the larger province of North Sumatra in August 1950, caused great resentment amongst the Acehnese revolutionary leadership. Such regionalist frustrations fused with opposition to Jakarta on the question of the basis of the state, resulting in largescale Acehnese participation in the Darul Islam (House of Islam) revolt in the 1950s. The rebels in Aceh maintained links with similar movements in West Java and Southern Sulawesi. Their explicit aim was to insure that the Indonesian state was based on Islam or, as Morris puts it, to insure that the "center was constituted as representative of the revolutionary heritage." 10 In 1958, even Hasan di Tiro, who two decades later established the secessionist Free Aceh Movement, published a book entitled Democracy for Indonesia, in which he argued in favor of an ethno-federal Indonesia, with Islam as its unifying cultural foundation. ${ }^{11}$

After the establishment of the Suharto government in the late 1960s, increasing authoritarianism and centralization ended early hopes that Aceh would exercise considerable autonomy under the "Special Territory" arrangements worked out to resolve the Darul Islam revolt. During the 1970s, large-scale mineral extraction projects (especially in the Arun natural gas field) formed enclaves within an overwhelmingly agrarian society and aroused resentment that Aceh's natural riches were being exploited to benefit "Java."12 In the background, the universalization of the nationstate system from the 1950s itself popularized the notion of a separate and sovereign state as the ultimate prize for every ethnic identity group worth its salt. These processes resulted in the formation of an, at first tiny, secessionist movement, Gerakan

\footnotetext{
${ }^{9}$ Eric Eugene Morris, Islam and Politics in Aceh: A Study of Center-Periphery Relations in Indonesia (PhD dissertation, Cornell University, 1983), p. 88.

10 Morris, Islam and Politics in Aceh, p. 175.

11 Hasan Muhammad Tiro, Demokrasi Untuk Indonesia (Jakarta: Teplok Press, 1999).

12 Tim Kell, The Roots of Acehnese Rebellion 1989-1992 (Ithaca: Cornell Modern Indonesia Project, 1995), p. 22.
} 
Aceh Merdeka (GAM, Free Aceh Movement) in $1976 .{ }^{13}$ The organization's leader was Hasan di Tiro, a descendant of a family of leading ulama who played a prominent role in the struggle against the Dutch. Subsequent rounds of indiscriminate military repression in the late 1970s, and especially from 1989 to the early 1990s, greatly deepened Acehnese alienation from the Indonesian state and increased popular support for secession. ${ }^{14}$ The fruits of these policies became evident in the two years following the May 1998 resignation of President Suharto, with the rapid growth of a peaceful movement for self-determination among Acehnese youth and students, exemplified in organizations like SIRA (Sentral Informasi Referendum Aceh, Aceh Referendum Information Center). Their popular appeal was demonstrated by a series of massive pro-referendum demonstrations in several Acehnese towns, including the provincial capital, Banda Aceh, in November 1999. During the same period, GAM dramatically expanded the scale and geographical scope of its insurgency. Indonesian security forces, despite early promises of a change of approach, quickly reverted to dirty war practices, policies that accelerated the region's descent into violence from early 1999. By mid-2001, a virtual state of war existed through much of the territory.

As should be clear from the preceding summary, contemporary Acehnese nationalism is primarily reactive in character. Not only did it emerge in response to the depredations of the Indonesian state, but the particular construction of Acehnese national identity promoted by GAM and similar nationalist groups was itself produced by a process of interaction with, and explicit differentiation from, official Indonesian representations of Indonesian national identity. ${ }^{15}$ Thus, one finds in GAM materials an emphasis on an ancient and glorious Acehnese past, which is deliberately counterpoised to the allegedly recent and inauthentic history of Indonesia, as well as a celebration of an immutable Acehnese ethnic identity, which is contrasted to an inherently fraudulent Indonesian-ness, depicted as little more than a front for Javanese dominance. This essay does not attempt to rebut the standard depiction of Acehnese secessionist nationalism as arising in response to the activities of the Indonesian state. Instead, its aim is to add an extra dimension to our understanding of Acehnese nationalism by discussing the constitutive impact that the international context has had on it.

\section{The International Setting: Sovereignty, Self-determination, and the Challenge of Globalization}

Acehnese nationalists base their claims for independence on a core principle of the modern nation-state era: the right of self-determination. This right is widely proclaimed to be a universal principle, indeed a foundation stone, of the international order. Since the consolidation of the UN system, secessionist movements of all

\footnotetext{
13 The official name of this organization is the ASNLF, or Acheh-Sumatra National Liberation Front. It is more widely known within Aceh by its Indonesian acronym, however, and for ease of reference, this usage is adopted in this essay.

14 Kell, Roots of Acehnese Rebellion; Geoffrey Robinson, "Rawan is as Rawan does: The Origins of Disorder in New Order Aceh," Indonesia 66 (1998): 127-156.

15 For an argument to this effect see Edward Aspinall, "Modernity, History and Ethnicity: Indonesian and Acehnese nationalism in conflict," forthcoming in Review of Indonesian and Malaysian Affairs.
} 
description have routinely made it the centerpiece of their claims for separate statehood. ${ }^{16}$ However, the application of the principle over the past half century has been greatly confused and subject to important limits.

The modern conception of the right of self-determination is commonly thought to have arisen from the growth and spread of nationalism in the nineteenth century, especially in East and Central Europe. At that time, the core aim of nationalism was the acquisition of a sovereign and independent state for each self-defined national group within the great multi-ethnic empires: "a state for every nation and all the nation in one state," as the adage put it. The right to national self-determination is also commonly viewed as having grown out of the concurrent spread of the democratic ideal, based as it was on the notion that "the people" should be the final source of political legitimacy and should be free to decide their government and, by implication, the polity to which they belonged. After World War I, the Wilsonian doctrine of selfdetermination was primarily aimed at resolving the nationalities problem in the areas governed by the Central Powers and was not intended to apply to the colonial empires of the victors. In the aftermath of World War II, however, the scope of the doctrine was extended greatly, as the dismantling of the colonial empires began and the nation-state system extended across almost the entire globe. The UN Charter embedded the concept of the right of self-determination in the decolonization process, declaring that "all peoples have the right to national self-determination." Since that time, the right has attained some recognition in international law and come to occupy its current position as an axiom in the creed of every anti-colonial and secessionist movement.

From the start, despite the claims of universality, the exercise of the right to selfdetermination has been subject to very significant limits. In particular, there has never been recognition of a general right to secession from sovereign states. This is partly because respect for territorial integrity is itself central to the notion of sovereign equality of states, and hence to the whole international system. ${ }^{17}$ Hostility to secession also derives from the more practical fear that an unfettered right of secession would give rise to an anarchic and potentially endless process of disintegration of the world's many multi-ethnic states. Historically, the most important limitation has been in the definition of what constitutes the "self" in self-determination: which groups are properly defined as the "people" to which the right applies? In response to this question, self-determination has been closely linked to the struggle against colonialism. ${ }^{18}$ In the dominant UN interpretation, with few exceptions, groups who constituted a "people" for the purposes of self-determination were the inhabitants of colonies.

\footnotetext{
${ }^{16}$ For example, assertion of the right of self-determination was a common theme in the various declarations of independence which brought about the end of Yugoslavia. See Aleksandar Pavkovic", "Recursive Secessions in Former Yugoslavia: Too Hard a Case for Theories of Secession?," Political Studies 48 (2000): 485-502.

17 Ruth Lapidoth, "Sovereignty in Transition," Journal of International Affairs 45,2 (1992): 325-346, esp. 339.

18 Allen Buchanan, "Self-Determination and the Right to Secede," Journal of International Affairs 45,2 (1992): 347-366, esp. 348. One of the first formulations of a "right" of peoples to self-determination appeared in the UN General Assembly Resolution on the Granting of Independence to Colonial Countries and Peoples, thus linking the concept to the decolonization process. See Michael Freeman, "Democracy and Dynamite: the Peoples' Right to Self-determination," Political Studies 44 (1996): 746-761, esp. 747-748.
} 
An important corollary of this interpretation imposes a rigid territorial limit on the definition of a "people": self-determination was only for peoples located within the boundaries of existing states or colonies. As Bartkus writes:

As the specific right of colonial peoples, the "self" of self-determination was restricted to colonial administrative units, despite their arbitrarily delimited territorial boundaries and despite the fact that many of these units had a greater variety of communities than the Austro-Hungarian Empire ever contended with. ${ }^{19}$

In part, this approach flowed from the historic association of sovereignty with states; in the old world of sovereign dynastic states, "The members of international society were . . . the sovereign states, not their populations." 20 The result was an elision between the categories of "people" and "state": a new (independent) state may succeed to and thereby replace an old (colonial) one, but with very few exceptions, the new states produced by decolonization adhered to colonial boundaries. Thus, "selfdetermination" has had little to do with "peoples" or "nations," understood as collectivities believing that they shared a common history, language, culture, or national destiny. As we shall see, this dominant interpretation of the doctrine of selfdetermination impels concepts of sovereignty and state succession to the center of the secessionist agenda.

From the start there were exceptions, although almost always with the consent of the states involved. During the process of decolonization itself, there were cases where colonial borders were not sacrosanct (for example Cameroon or India). Even during the Cold War, when the great powers were reluctant to open the Pandora's box of secession, there were several cases of successful secession or state partition (Senegal from Mali in 1960, Singapore from the Malaysian Federation in 1965, and Bangladesh from Pakistan in 1971). In the past decade, there have been even more cases of successful secession: the dissolution of Yugoslavia and the Soviet Union, and the founding of Eritrea (1993), Slovakia (1993) and, arguably, East Timor.

In some such cases (Bangladesh, Yugoslavia, Slovakia), the newly independent states could not justifiably be described as successor states to historical sovereign states or colonial units. Even so, the international consensus has continued to deny a generalized right of secession. For example, following declarations of independence by Slovenia and Croatia, a commission established by the European Community restrictively interpreted Yugoslavia's breakdown as the dissolution of a federal system, whereby the constituent federal units were freed to go their separate ways. By doing so, even if this interpretation was difficult to square with the facts, the commission studiously avoided acknowledging a general right of secession. ${ }^{21}$

The classical concepts of sovereignty and self-determination might well appear in retrospect to have reached their apogee during the Cold War, as many writers on globalization have argued. Two phenomena associated with globalization constitute particularly direct challenges to state sovereignty and have had a significant impact on

${ }^{19}$ Viva Ona Bartkus, The Dynamic of Secession (Cambridge: Cambridge University Press, 1999), p. 11.

${ }^{20}$ James Mayall, "Sovereignty, Nationalism and Self-determination," Political Studies 47 (1999): 474-502, esp. 476.

21 Pavkovic', "Recursive Secessions," pp. 485-86. 
nationalism in Aceh. The first, the doctrine of universal human rights, has been important in the international arena for the last fifty years, but has been especially influential since the mid-1980s. Set down in the UN Declaration of Human Rights during the birth of the modern era of the universal nation-state, the concept of universal human rights has since been elaborated into a formidable "normative architecture" and has become embedded within a rapidly evolving system of international humanitarian law. ${ }^{22}$ Especially in the wake of the end of the Cold War, human rights issues have increasingly permeated the public discourse of international relations and the policies of states, although, as we know too well, they have not yet dominated them. The concept of universal human rights shares Enlightenment origins with nationalism, for these two ideas are linked in part by the concept of popular sovereignty. However, recent experience indicates that human rights discourse and practice may, indeed must, come into conflict with the nationalist impulse and the defense of sovereignty. In part, this happens because of the exclusionary logic of ethnic (and other) nationalisms, which legitimate coercive action against those who are deemed to threaten the authenticity of the national community or the integrity of the state. Human rights doctrines challenge the nation-state by laying down universal standards which claim to transcend all defenses based on state sovereignty, unique national identity, or national interest. As Sikkink argues, "international human rights norms question state rule over society and national sovereignty" and thus "offer particularly potent challenges to the central logic of a system of sovereign states." 23

The growing influence of universal human rights, plus the proliferation of actual cases of state dissolution since the end of the Cold War, have combined to challenge theory on self-determination. Hence for example, Kofman suggests that some "territorial groups with historical-cultural identities" should be granted a qualified right to secede, provided that they "cannot be aiming to deprive the former state of its most important resource base, and they must be willing to respect the individual and cultural rights of their own minorities ... "24 Similarly, Buchanan argues that there should be a limited right of secession in cases of "discriminatory redistribution" or where there are genuine threats of cultural extinction which could not be remedied by a lesser measure. ${ }^{25}$ Freeman notes that one of the most common grounds for arguing in favor of extending the right of secession is "the remedial theory of secession" which associates "the right of secession with the right to resist tyranny." 26 In this view, oppression is the "necessary condition for the right of secession." 27

The second element of globalization considered in this article, itself related to the growth of the international human rights regime, is the appearance of new kinds of

22 Richard A. Falk, Human Rights Horizons: The Pursuit of Justice in a Globalizing World (New York: Routledge, 2000), p. 54.

${ }^{23}$ Kathryn Sikkink, "Transnational politics, international relations theory, and human rights: a new model of international politics is needed to explain the politics of human rights," PS: Political Science and Politics 31,3 (1998): 517-521, esp. 517.

24 Daniel Kofman, "Rights of secession," Society 35,5 (1998): 30-37, esp. 37.

25 Buchanan, "Self-Determination and the Right to Secede," p. 354.

${ }^{26}$ Freeman, "Democracy and Dynamite," p. 753.

27 See also Lee C. Buchheit, Secession: The Legitimacy of Self-determination (New Haven: Yale University Press, 1978). 
transnational organizations, collectively constituting an emergent global civil society. These networks, particularly those associated with the major human rights nongovernmental organizations (NGOs), play a crucial role as sites for the development and inculcation of new human rights norms and in modifying "the conflictual nature of socially constructed anarchy" embedded in the Westphalian system. ${ }^{28}$ By promoting universal norms, maintaining transnational institutional forms, and campaigning across national borders, such organizations themselves have the potential to undermine or challenge the core principles of the nation-state system, including state sovereignty. The Acehnese experience suggests that global civil society networks may play a direct role in seeking to moderate conflict between rival nationalisms with mutually incompatible claims for sovereignty.

\section{The International Structuring of Acehnese Nationalism}

Like participants in all secessionist movements, Acehnese nationalists make many appeals for international support. This is not surprising, given that, except in cases where the state which encased the secessionist minority has acceded to separation (as Czechoslovakia did in the case of Slovakia, for example), the only secessionist movements that have proven successful are those that benefited from international support, either in the form of military backing (from India in the case of Bangladesh) or in the form of swift recognition of claims for statehood (from the US and European countries in the case of the former Yugoslav republics) ${ }^{29}$ Even where secessionist movements exercise effective control over all or most of the territory to which they lay claim (and for a period in 1999-2001 GAM did control large swathes of the Acehnese countryside), this counts for little in the absence of formal recognition of statehood and entry into the community of nation-states via appropriate UN mechanisms.

From the start, Hasan di Tiro and other GAM leaders appreciated the need to attain international support and recognition. In the late 1970s and early 1980s, they argued strongly for international recognition of Acehnese sovereignty. Ignored by the Western powers and influenced by the Cold War context of the time, they adopted a sometimes strident third-worldist, anti-imperialist tone, describing Indonesia as a neocolonial tool for the exploitation of the natural resources of Aceh and other parts of the archipelago. This was the period when foreign investment was flooding back into Indonesia after the overthrow of Sukarno government; Aceh attracted major investments in gas and timber. In the 1970s, GAM combatants mounted operations

\footnotetext{
${ }^{28}$ Ronnie D. Lipschutz, "Reconstructing World Politics: The Emergence of Global Civil Society," Millennium: Journal of International Studies 21, 3 (1992): 389-420, esp. p. 390.

${ }^{29}$ For an argument that international recognition was the crucial factor in the Yugoslav dissolution, see Raju G. C. Thomas, "Self-determination and international recognition policy: an alternative interpretation of why Yugoslavia disintegrated," World Affairs 160,1 (1997): 17-33.
} 
against foreign companies operating in the province. ${ }^{30}$ In the 1980 s, GAM turned to Libya for support at a time when Colonel Gaddafi was promoting himself as the new international leader of all manner of national liberation movements; several hundred GAM members eventually received military training in that country.

In the post-Cold War era of "humanitarian intervention," Acehnese nationalists have been far more hopeful about the possibility of gaining support from the UN and the major powers (especially the US), and have reoriented their attentions accordingly. Appeals for international assistance or intervention have become central to the demands of almost every civil society or political group in Aceh, except for those with links to the government. Many groups have focused on encouraging international human rights bodies to take an interest in Aceh, in order to restrain Indonesian security forces from abusing the civilian population. ${ }^{31}$ Especially after President Habibie promised East Timor a referendum on independence, calls for the $\mathrm{UN}$ to organize a similar process in Aceh became central to the agenda of many Acehnese groups (most notably SIRA). At times, activists have adopted creative methods of furthering this campaign, such as the coordinated attempts to fly UN rather than Indonesian flags en masse through Acehnese territory on the anniversary of Indonesian independence in August 2000.32 In recent years, almost every public statement made by even relatively junior GAM field commanders-and innumerable such statements are reported by the Acehnese and North Sumatran-based press-includes a call for international recognition or intervention of some kind.

The appeal for international support is more than a mere tactical device. It can itself be an assertion of national status (along the lines of "we are as important as any other nation-state and demand equal recognition"). At the same time, awareness of an international audience has left a distinct and important imprint on the discourse of the various pro-independence groups, even on their very conceptualization of Acehnese identity.

\section{Indonesian Control as Colonialism}

One core feature of Acehnese nationalist discourse is its characterization of Indonesian rule as colonial. This theme is particularly prominent in writings and statements by leaders of GAM, but it also routinely appears in material linked to newer youth and student-led self-determination organizations like SIRA. In materials produced by such groups, the Indonesian government is routinely characterized as the "Javanese colonial government" (pemerintah penjajah Jawa: this or some close equivalent tends to be the favored choice for GAM), or the "neo-colonial Indonesian government" (such terms being more commonly used by younger activists). Indonesian "colonialism" is depicted as having a cultural dimension (as it propagates "Javanese" cultural values, for example by the transmigration program), an economic dimension (as it exploits Aceh's natural resources for the benefit of "Java"), and a political dimension

\footnotetext{
${ }^{30}$ For Hasan di Tiro's account of such operations and the justification for them, see his The Price of Freedom (The Unfinished Diary) (Norsborg: Information Department, National Liberation Front Acheh Sumatra, 1981), pp. 168-171, 195-196.

31 See for example, "'Ganjalan' Penyelesaian Pelanggaran HAM," Kontras, May 23- 29, 2001.

32 "Soal Merah-Putih, Siapapun jangan Memaksa, Bendera PBB tak Boleh Berkibar," Serambi Indonesia, August 16, 2000.
} 
(since "Javanese" dominate the bureaucracy and Armed Forces). Those Acehnese who work for the Indonesian state are likewise commonly described as servants or lackeys (antek) of colonialism. ${ }^{33}$

GAM uses the reference to colonialism in order to justify violent resistance against the Indonesian state in language derived from international law. As GAM spokesperson for the Peureulak region, Ishak Daud, put it after one attack on a military convoy:

As a colonized nation, [the Acehnese] are granted the right by the UN to resist the colonialists by all means, including by using arms. Because colonialism is viewed as an international crime ... We request that all civilized nations, particularly the members of the UN, obey UN resolutions. Because therein it is said that all member nations of the UN are obliged to finish off the colonialists. They also prohibit anyone whatsoever from using violence against those nations which are struggling for their freedom. ${ }^{34}$

The description of Indonesian control as colonial in nature is partly directed at an internal Acehnese audience and is intended to instill a sense of continuity with past struggles against the Dutch. However, as the above quotation suggests, it also partly aims to shape Acehnese demands in accordance with international norms of selfdetermination, given that self-determination has been historically linked to decolonization. As Benyamin Neuberger outlines (with particular reference to movements in Africa), secessionist movements habitually equate their demands for separate statehood with struggles against colonial rule, describing their oppressors as imperialists and themselves as engaged in anticolonial struggle. The aim, clearly, is to "base their claims on a universally legitimized principle of national selfdetermination." 35

However, Neuberger also notes that such claims typically fail to resonate in the international community and lack validity in international law. This happens, he points out, because the UN has effectively accepted what are often disparagingly referred to as the "saltwater" and "pigmentation" definitions of colonies. The first holds that for control to be deemed colonial, the colony must be separated from the imperial power by ocean, the second that the colonial power must be a different racial group (usually European) from those colonized. The UN has thus defined a colony as an entity that is "geographically separate and distinct ethnically and/or culturally from the country administering it." 36

Partly in response to this objection, Acehnese nationalists historicize "Indonesian colonialism" by depicting it as a continuation of Dutch rule, and by describing their own struggle as an extension of opposition to the Dutch. This view is part of an argument which, since the 1976 formation of GAM, has occupied a central place in the movement's demands for international recognition. This is the argument that a

\footnotetext{
33 See for example, "DPRD Tidak Bermanfaat," Serambi Indonesia, May 10, 2001.

34 "GAM Serang Konvoi Reo di Aceh Timur," Serambi Indonesia, May 15, 2001.

35 Ralph Benyamin Neuberger, National Self-Determination in Postcolonial Africa (Boulder, CO: Lynne Reinner Publishers, 1986), p. 90.

36 Ibid., p. 84.
} 
contemporary independent Aceh (an entity that GAM leaders claim has had de jure existence since Hasan di Tiro's "re-declaration" of independence in 1976) is a successor state to the nineteenth-century Sultanate.

\section{Acehnese History and the Successor State Idea}

Secessionist movements frequently justify their claims to self-determination by constructing ethno-histories of independent statehood stretching back to antiquity. ${ }^{37}$ Acehnese nationalism has a particularly marked atavistic element of this sort. Writings and statements by, and published interviews with, GAM leaders are full of references to the golden age of the Acehnese Sultanate, especially under the seventeenth-century Sultan Iskandar Muda, and to the nineteenth-century anti-Dutch war. Once again, such claims are partly directed inward and are aimed at constructing a nationalist constituency within Aceh. By presenting an image of a glorious, ancient, and independent Acehnese state and its pernicious subjugation by Dutch and Indonesians, Acehnese nationalists such as Hasan di Tiro strive to "awaken" current generations of Acehnese to the responsibilities bequeathed to them by their forebears. ${ }^{38}$

The references to history are also intended, however, to establish a legal basis for independent statehood in the language of international law. GAM leaders routinely argue that an independent Aceh (as represented by their own organization) is the successor, indeed the continuation, of the precolonial Acehnese Sultanate. There are at least three distinct steps in the argument.

The first step is to show that the Acehnese Sultanate was a legitimate sovereign actor in the international state system. This is not a problematic proposition for Acehnese nationalists to establish, and they routinely emphasize events like the dispatch of ambassadors by the Sultanate to European and other states, statements by foreign heads of state giving recognition to Acehnese sovereignty, and the treaties entered into by Aceh. Prominent among these is the 1819 treaty negotiated between the sultanate and Sir Stamford Raffles. It is on the basis of the latter that Hasan di Tiro has gone on the record suggesting that an independent Aceh might choose to become a member of the British Commonwealth. ${ }^{39}$

The second step is to establish that the initial assault on the Acehnese Sultanate and the subsequent attempt to incorporate it into the Dutch East Indies was illegal. The key date here is 1873 , when the Dutch issued a formal declaration of war and invaded Aceh (although they took several decades to subdue the territory). Acehnese nationalists, especially but not exclusively those associated with GAM, argue that this Dutch attack on Aceh amounted to an illegal annexation similar to Indonesia's 1975 annexation of East Timor. They also note the positions taken by various foreign powers at this point, especially the official neutrality adopted by the United States. In short, Acehnese nationalists attempt to ground their claim on what Buchanan calls the

37 Smith, National Identity, pp. 126-127; Neuberger, National Self-Determination, pp. 42-52.

38 For more discussion of Acehnese historical claims, see Gerry van Klinken, "The Battle for History after Suharto: Beyond Sacred Dates, Great Men, and Legal Milestones," Criticial Asian Studies 33,3 (2001): 323 350, esp. 337-340; Aspinall, "Modernity, History and Ethnicity."

39 "Saya Ingin Aceh Jadi Commonwealth Inggris," Forum Keadilan, April 2, 2000, pp. 78-81. 
principle of "rectificatory justice," whereby "secession is simply the reappropriation, by the legitimate owners, of stolen property." 40

However, in order to establish the application of this principle to contemporary Aceh, GAM leaders must take a third, more difficult, step. This requires them to prove that Aceh's incorporation into the Netherlands East Indies and Indonesia never became legally valid. To make this point, they argue that Aceh was never defeated by the Dutch and that a state of war between Aceh and the Netherlands East Indies continued until the Dutch were forced to leave Aceh in 1942. Then, the argument continues, at the 1949 Round Table conference in The Hague, Holland transferred sovereignty (which it did not legally possess) over Aceh to the new colonizer, Indonesia. This transfer of sovereignty was an illegal act upon which Indonesian claims to Aceh now rest. 41

In order to bolster this argument, Acehnese nationalist accounts must systematically reinterpret a range of episodes in Acehnese history which in standard Indonesian accounts validate Acehnese incorporation into the Netherlands East Indies and Indonesia. For example, although Dutch officials early last century usually spoke of the "pacification" of Aceh, some Dutch and Indonesian accounts also suggest that the Acehnese surrendered to the Dutch, effectively legalizing the latter's control over Acehnese territory. ${ }^{42}$ GAM spokespeople deny that this was the case. They argue that either after or before the surrender of the Sultan Tuanku Muhammad Daud Shah in 1903, the mandate of wali negara (guardian or head of state) passed to the family of the famous ulama Tengku Chik Di Tiro Muhammad Saman, the great-grandfather of Hasan di Tiro, and that Hasan di Tiro has himself inherited this mandate. ${ }^{43}$ They similarly argue that Aceh was not legally incorporated into Indonesia when the latter achieved independence in 1945-49. They do this by challenging accepted Indonesian

40 Buchanan, "Self-Determination," p. 353.

41 A chief source for these arguments is Tiro, The Price of Freedom, esp. pp. 24-25, but they can be found in numerous other writings and statements by GAM leaders. See for example, "Pernyataan Teuku

Hidayatullah M dari Markas GAM," Kompas, August 12, 1999, in which a GAM leader from North Aceh writes of the "Sovereignty of the State of Aceh which was seized illegally by the Dutch government, and then surrendered illegally to the Government of the Republic of Indonesia."

42 See for example comments by University of Gadjah Mada historian Ibrahim Alfian "Aceh Merdeka, Hasan Tiro, dan Satu Tafsir Sejarah," Tempo, June 18, 2000, pp. 47-50, esp. 50.

43 See for example, comments by Abu Sofyan Daud, vice-Commander of GAM for the Pase district in "Wali Nanggroe, Kok bukan Hasan Tiro?," Kontras, July 4-10, 2001. Some GAM leaders even assert that the mandate of wali negara passed to Tengku Chik Di Tiro Muhammad Saman in 1874 when Sultan Muhammad Daud Shah died, leaving only a twelve-year-old son. This son, however, was himself declared of age in 1884 , and it was he who, as sultan, surrendered to the Dutch in 1903. See Anthony Reid, The Contest for North Sumatra: Acheh, the Netherlands and Britain 1858-1898 (London: Oxford University Press, 1969), p. 31. In the GAM view, several of Tengku Chik Di Tiro's male descendants continued as wali negara after this point, although they were killed in quick succession by the Dutch. The last was Tengku Chik Ma'at di Tiro, Hasan di Tiro's uncle who, as the sixteen-year-old "last Head of State of Free Aceh," was killed on the battlefield in 1911. See Tiro, The Price of Freedom, p. 11. Hasan di Tiro's claim to the title of wali negara is disputed by opponents, including splinter groups within GAM. Husaini Hasan, for example, argues that power was only temporarily transferred to Tengku Chik di Tiro Muhammad Saman, without the transfer of a hereditary right to become head of state. Many Acehnese historians agree that there was never a transfer of unfettered sovereign power. See "Aceh Merdeka, Hasan Tiro, dan Satu Tafsir Sejarah," Tempo, June 18, 2000, pp. 47-50, esp. 49. 
interpretations of key historic incidents, like a famous declaration of loyalty to "our homeland Indonesia" made by four leading Acehnese ulama on October 15, 1945.44 Acehnese nationalists contend that this was merely a statement by four individuals, with no binding legal authority over the entire population, and that "the integration of Aceh [into Indonesia] was done by just a few people, whereas Aceh, as we know, is not the property of just a few." 45 Acehnese nationalists find it especially problematic to deal with the first three decades of Indonesian independence, before secessionist aspirations had been publicly voiced and when, even at the height of the Darul Islam rebellion, there remained considerable commitment to a united Indonesia among Aceh's leaders (including Hasan di Tiro himself, as his 1958 book, "Democracy for Indonesia," makes clear). Acehnese nationalists frequently either skim over this period or depict it as a period of temporary loss of national consciousness. ${ }^{46}$ They also sometimes attempt to reinterpret this period in the light of current nationalist orthodoxy, for example by emphasizing the anti-Jakarta element in Darul Islam and obscuring the programmatic distinctions between it and the contemporary insurgency.

By such methods, Acehnese nationalists depict Indonesian rule as, legally, a continuation of Dutch rule. In the early years of GAM, Hasan di Tiro and other leaders of the organization used to describe Indonesia as an "invention" of the Dutch and other foreign powers, designed to allow continued neocolonial exploitation of the archipelago ${ }^{47}$ From the early 1990s, when the movement's leaders began to abandon anti-"neo-colonial" rhetoric in the interests of garnering Western support, many Acehnese nationalists maintained the legal fiction that their conflict was really with Holland. In the words of the late commander of the armed wing of GAM, Abdullah Syafi'ie: "It is only the government of Holland which has the right to conclude its warfare with the Acehnese nation which began on March 26, 1873."48

Such historic claims are partly used to construct national identity for a domestic Acehnese audience. In the "unfinished diary" of his sojourn in the mountains of Aceh during 1976-79, Hasan di Tiro frequently stresses that the key initial challenge facing Acehnese nationalists was to awaken the Acehnese population to their national destiny. This, he believed, could be achieved by teaching the people both about Acehnese history and about international affairs and international law. ${ }^{49}$ In the postSuharto period, GAM leaders frequently emphasize Aceh's historically derived legal right to independence when making speeches to audiences in Acehnese villages or when giving interviews to local newspapers. Exactly the same arguments recur when GAM leaders address international audiences, suggesting that they genuinely believe in the legality of their claim for independent statehood. 50

\footnotetext{
44 See Syarifuddin Tippe, Aceh di Persimpangan Jalan (Jakarta: Pustaka Cidesindo, 2000), pp. 31-32, for one Indonesian nationalist account of this event.

45 Muhammad Nazar, "Pelaksanaan Referendum Aceh; Mengakhiri Konflik Warisan," Suwa 1,1 (2000): 7.

46 For example Tiro, The Price of Freedom, p. 28.

47 Ibid., p. 168.

48 "GAM Tak Mau Gencatan Senjata," Waspada, December 5, 1999.

49 Tiro, The Price of Freedom, p. 194.

${ }^{50}$ For one example see the following article based on an interview with "Prince" Hasan di Tiro: Arnold Beichman, "Destined for Rebellions? Acehnese Independence Cries for Justice," Washington Post, June 18, 2001.
} 
The main point to be derived from the preceding discussion is that Acehnese nationalist claims, and the nationalist interpretation of Acehnese identity, have been shaped through interaction with the international system, even through the process of globalization itself. The arguments about Aceh's historical and legal rights to independence were largely developed by Hasan di Tiro and other nationalist leaders while in exile. Their views reflect the romanticism typical of what Anderson calls the long-distance nationalist, as well as the frustrations of those seeking international recognition and support. ${ }^{51}$ Hasan di Tiro himself was in the United States as a member of Indonesia's UN delegation when the Darul Islam rebellion broke out, and he appointed himself spokesperson for that movement. ${ }^{22} \mathrm{He}$ spent most of the succeeding two and half decades in the US, until his secret return to Aceh in 1976, when he founded GAM. The GAM leader himself emphasizes the influence on his political views of his "about 20 years" training in political science, international law, and related topics at American universities, including Columbia and Fordham. ${ }^{53}$ From the 1970s, he and his close supporters, who eventually established themselves in Sweden after Hasan di Tiro fled Aceh in 1979, expended considerable energy attempting to gain entry into major international organizations and to obtain international recognition for GAM as the legitimate representative of the Acehnese people. The most that they could achieve was access to the outermost fringes of the international system, via such bodies as UNPO (Unrepresented Nations and Peoples Organization), and they frequently expressed intense bitterness at the indifference of the UN and the major powers toward the Acehnese cause. ${ }^{54}$

The GAM doctrine that designates an independent Aceh as the successor state to the old sultanate has some important corollaries. In the first place, it has important implications for the form of state to be adopted by an independent Aceh. GAM leaders have never presented a clear blueprint of what kind of constitutional system will be adopted in Aceh after it achieves independence. In particular, they have made few attempts to convince potential overseas sympathizers that a democratic system will be put in place. This course of action relates directly to the view held by the organization's leaders that there is an unbroken continuity between the nineteenthcentury status quo ante and the present. This means, among other things, that Hasan di Tiro is the legal sovereign and that upon his death his son, Karim, will assume the title of wali negara (although there is debate about this second point in GAM circles). It also means that, upon achieving de facto independence (as opposed to de jure independence, which GAM leaders already claim), the constitutional and political structures adopted will be those of the nineteenth-century sultanate. Some GAM leaders stress that this does not rule out constitutional reform after independence, when consultation with the population can be carried out. This reform, however, is

51 Benedict Anderson, "The New World Disorder," New Left Review 193 (1992): 3-13, esp. 12-13.

52 M. Isa Sulaiman, Aceh Merdeka. Ideologi, Kepemimpinan dan Gerakan (Jakarta Timur: Pustaka AlKautsar, 2000), pp 12-13.

53 Tiro, The Price of Freedom, pp. 162-63.

54 See for example Hasan di Tiro's speech before the UNPO General Assembly: The New-Colonialism; Denominated "Indonesians!" Delivered at The Hague, January 20, 1995. Accessed online at http://acehnet.tripod.com/ colonial.htm. 
relegated to a vague and distant future. In the words of Abu Sofyan Daud, ViceCommander of GAM for the Pase region:

In the future, if Acehnese independence is achieved, the form of state and position of head of state can be agreed upon again: whether it will be a monarchy, a republic, or something else. Likewise, whether the head of state will be held by a sultan, king, wali, or president. That's an agenda for the future, after independence is achieved. It will all be up to the people's choice..$^{55}$

A second corollary has to do with the territorial boundaries of an independent Aceh, which this doctrine would draw following the outlines of the sultanate, which were and still are vaguely defined. Early on in the history of GAM, Hasan di Tiro stated that the "minimum legal claim" for Acehnese territory included all land encompassed by the historical boundaries in place at the time of the Dutch attack in 1873. In his view, these incorporated Bengkulu, Jambi, and the Riau Archipelago, an enormous area of Sumatra, including six other present-day Indonesian provinces, far exceeding the area inhabited by ethnic Acehnese..$^{56}$ Indeed, Hasan di Tiro went further, claiming sovereignty over the entire island of Sumatra (which after independence would be governed as a federation), because "the Southern part of Sumatra was taken by the Dutch from Acheh through the process of creeping colonial war prior to March 26, 1873." 57

Contested territorial claims are frequently one of the most problematic aspects of atavistic ethno-nationalisms. The wars in the former Yugoslavia amply testify to this, as do conflicts in Mindanao, where historical claims based on the suzerainty of the Sulu and Maguindanao sultanates are undermined by the contemporary minority status of Muslims due to a century of migration by Christian Filipinos. Even in the world annals of ethno-nationalism, however, Hasan di Tiro's claims for a vast historic Acehnese homeland stand out as notably ambitious. It is true that during the golden age of the sultanate's power under Iskandar Muda "royal control was effective over all the important ports of the west coast of Sumatra as well as the east coast as far south as Asahan." 58 But this control consisted essentially of projection of naval power, payment of tribute to the Sultanate, and acknowledgment by local rulers of its ultimate authority. It was certainly not equivalent to modern notions of state control over sovereign territory. In any case, within a few decades of Iskandar Muda's death in 1636, the sultanate's geographical reach shrank dramatically, so that its maximum nineteenth-century claims did not extend far beyond the present-day province of Aceh on the west coast, although they did take in much of the adjacent coastal regions of the contemporary province of North Sumatra on the east.

Even in the post-Suharto period, there remains considerable uncertainty about the extent of Acehnese nationalist territorial claims. GAM spokespersons frequently still blur the distinction between "Sumatra" and "Aceh." 59 In private, however, some GAM

55 "Otonomi Khusus Berbentuk NAD, Itu bukan Utang," Kontras, July 4-10, 2001.

56 Tiro, The Price of Freedom, p. 148.

57 Ibid., p. 149.

58 Reid, Contest for North Sumatra, p. 3.

59 See for example comments by GAM spokesperson for the Peureulak region, Ishak Daud in "GAM Minta PBB Segera Selesaikan Masalah Aceh" Waspada, April 30, 2001. 
leaders are ready to concede that they would accept the present provincial borders as the boundary of an independent state..$^{60}$ For this reason, they are vehemently opposed to proposals by local elites in some parts of Aceh-such as the predominantly nonethnic Acehnese districts of Central Aceh, Southeast Aceh, and Singkil-to break away from Aceh and form one or two separate provinces.

In summary, and putting to one side the ambiguity over territorial boundaries, we can see that the essence of the claim made by GAM and like-minded Acehnese nationalists is for the classical form of sovereignty which came to be embedded in and universalized by the United Nations system in the post-World War II years. This implies, among other things, judicial equality with other states, inviolability of Acehnese territorial integrity, and exclusive power over its own territory. In order to achieve this, Acehnese nationalists have felt compelled to construct their claim within the accepted idiom of the international system.

To an outsider, it seems obvious that such claims have little chance of recognition under international law. Many writers have criticized Hasan di Tiro for the "romanticism" of his view of history and Acehnese statehood. ${ }^{61}$ Gerry van Klinken has described it as "purely propagandistic." 62 Certainly, established practice in the postWorld War II order, especially the identification of self-determination with decolonization and the adherence to former colonial boundaries, stands hard against Acehnese claims. Likewise, whatever Acehnese nationalists may claim about the validity of Dutch and Indonesian sovereignty, it is clear that Aceh was administratively incorporated into the Dutch East Indies and the modern Indonesian Republic, bringing into play the principle that states are assumed to have valid sovereignty over territory they control (uti possidetis). Even so, one may sympathize with Acehnese nationalists for feeling obliged to make these arguments in an international system that provides little space for minorities with aspirations for statehood, even those who have been severely repressed by the state from which they seek to escape. There is little doubt that, at least in the immediate post-Suharto years, a majority of the Acehnese population wishes to be rid of the Indonesian state; senior Indonesian officials have occasionally admitted as much. ${ }^{63}$ Yet the position of the Acehnese is completely different in international law from, say, the position of the East Timorese, because in the colonial division of Southeast Asia, East Timor was colonized by the Portuguese, while for a brief half century the Acehnese were vanquished by the Dutch. Also, unlike the East Timorese, who were integrated into Indonesia by force, the weight of historical evidence suggests that the majority of Acehnese leaders, at least, voluntarily acceded to union with Indonesia in 1945. But even if this was the case, should such a voluntary agreement to enter into a state be binding for all time?

\footnotetext{
60 Confidential interviews, January-February 2001.

61 For example, Finngeir Hiorth, "Free Aceh: An Impossible Dream?" Kabar Seberang: Sulating Maphilindo 17 (1986): 182-94; Kell, Roots of Acehnese Rebellion, p. 63.

62 Van Klinken, "The Battle for History," p. 339.

${ }^{63}$ For example Commander of the Bukit Barisan military command, Major General Abdul Rahman Ghafar, in late 1999 said that a majority of the Acehnese would choose independence if offered a referendum:

"Ulama Sesalkan Presiden tak Kunjungi Aceh," Republika, November 12, 1999.
} 


\section{Universal Human Rights and the Refashioning of Acehnese Claims}

It is partly in response to this predicament that many Acehnese nationalists have turned to an alternative range of arguments associated with universal human rights. The description of Acehnese suffering under Indonesia's repressive rule figures as a central theme in the discourse of a large variety of Acehnese political groups, ranging from GAM to NGOs which do not formally support self-determination. Most nationalist political activists (and many members of the Acehnese elite who do not openly endorse independence) will, when questioned, cite the brutality of the Indonesian army as the main reason why Aceh should seek its independence.

When Acehnese groups discuss military abuses, they increasingly do so in the idiom of the developing international human rights discourse. Human rights organizations have proliferated in Aceh since 1998, and international human rights NGOs and other agencies have shown an increased interest in Aceh during the same period. What's more, events leading up to the referendum in East Timor demonstrated the power and efficacy of international humanitarian intervention. These developments have combined to inject acute awareness of the international context into contemporary Acehnese discussions of military abuses. Newspaper reports of violations are peppered with references to the Universal Declaration of Human Rights and other relevant instruments. Acehnese human rights activists have appeared before the UN Sub-commission on Human Rights in Geneva, and cooperated with the major international human rights NGOs. NGOs, student groups, and GAM routinely mold their condemnations of abuses in a way intended to appeal to UN and other international agencies. To cite one example: taking a lesson from the international response to the Yugoslav civil wars and the Rwandan genocide, Acehnese activists now frequently accuse the Indonesian state of carrying out racial discrimination, ethnic cleansing (pembersihan etnis), and even genocide against the Acehnese "ethnic group" (hence the growing use of the English-derived terms etnis and etnik, rather than the hitherto popular and more obviously nationalist bangsa). ${ }^{64}$

As noted above, especially since the Yugoslav and Soviet dissolutions, and coinciding with the greater international prominence of universal human rights, some philosophers and other writers have promoted a "remedial theory of secession." They argue in favor of extending the right of self-determination beyond the colonial context, to cases of extreme discrimination, genocide, or some other abuse of the population. In such cases, it is argued, the state has lost the moral right to govern. Tamara Dragadze notes that some secessionist movements (she refers to that in Chechnya) frame their claims in this way. ${ }^{65}$

Since the public exposure of Suharto-era military abuses in 1998-1999, some Acehnese writers and activists have adopted this kind of argument. Many unaffiliated intellectuals, younger activists outside GAM ranks, and members of the provincial political elite do not accept, or at least do not emphasize, the successor-state argument

64 See for example, "Buffer Aksi Jeumpa Mirah Gelar Unjuk Rasa Damai di Banda Aceh," Analisa, May 3 , 2001.

65 Tamara Dragadze, "Self-determination and the politics of exclusion," Ethnic and Racial Studies 19,2 (1996): 341-351, esp. 347. 
that Indonesian sovereignty over Aceh was illegal from the start. ${ }^{66}$ Instead, they argue that even if the Acehnese population gave voluntary assent to incorporation with Indonesia, such a voluntary union should not necessarily be permanently binding, but might be invalidated if the state forfeits its moral authority to rule. In the burgeoning Indonesian/Acehnese literature on the "Aceh problem," one frequently encounters the argument that Aceh's early loyalty to the Republic has been repaid with violence and that this betrayal accounts for the growth of secessionist sentiment. ${ }^{67}$ Writers often employ a marriage metaphor: after many years of enduring deceitful and violent treatment, the Acehnese "wife" has valid cause to seek a divorce from the Indonesian "husband." 68 Such arguments imply a contractual understanding of state sovereignty, whereby sovereignty is viewed as residing with the people in the form of political consent, which may be withdrawn. The important point is that some activists, taking the logical next step, argue that this betrayal of trust is grounds for selfdetermination. ${ }^{69}$

A shift in paradigm is thus apparent in the character of the political demands made by groups outside of GAM. The core demand advanced by various youth and student organizations, like SIRA, has been for a referendum that includes an independence option. This is not presented as a non-negotiable demand for recognition of an eternal Acehnese sovereignty, but rather as a democratic and just method to resolve the conflict in Aceh by determining the aspirations of the population. ${ }^{70}$ In the words of Muhammad Nazar, Coordinator of SIRA, the ideological conflict between the two warring sides in Aceh has given rise to "political stagnation":

The military is given authority by the Government to say that Aceh is a part of the Unitary State of the Republic of Indonesia that must be maintained until the last drop of blood. Meanwhile, the Free Aceh Movement, which was proclaimed by Hasan Tiro in 1976, says that Aceh is not a part of Indonesia, meaning that Aceh must oppose every act of intervention and colonialism by other states. The consequences are certain, namely that the civilian population shed their blood, their tears, and lose their possessions. Shall we let this occur? . . . the people of

\footnotetext{
66 James Siegel notes that many students who favor independence show little interest in Hasan di Tiro's views. See James Siegel, "Possessed," in The Rope of God, 2nd ed. (Ann Arbor: University of Michigan Press, 2000), pp. 336-442, esp. 362 .

67 See for example Al-Chaidar, Sayed Mudhahar Hamid, and Yarmen Dinamika, Aceh Bersimbah Darah: Mengungkap Status Daerah Operasi Militer (DOM) di Aceh 1989 - 1998 (Jakarta: Pustaka Al-Kaustar, 1999).

68 During the August 2000 People's Consultative Assembly (Majelis Pemusyawaratan Rakyat, MPR) session in Jakarta, at which the author was present, Ghazali Abbas Adnan, an outspoken Acehnese member of the Islamic-based United Development Party (Partai Persatuan Pembangunan, PPP) made this point in an interruption of proceedings. He condemned the body's lack of interest in Aceh's plight and suggested that the Acehnese viewed the relationship between Aceh and the central government as being like that between a husband and wife. At the outset of the "marriage" in 1945, the Acehnese hoped for a "husband" who would love and respect them. Instead, they have been abused and had their possessions stolen. In such circumstances, he argued, "many thought" it was appropriate for the Acehnese "wife" to divorce her husband.

69 See comments by student activists in "Mahasiswa Aceh Tuntut PBB Dukung Referendum di Aceh," Kompas, March 23, 1999.

70 See for example "SIRA: Referendum Bukan Separatis," Waspada, June 191999.
} 
Aceh are committed to a comprehensive peace process, which can only be achieved via the implementation of a referendum.

Moreover, according to Nazar, self-determination is a "part of universal human rights recognized by UN resolutions, international law, and the Geneva convention." A referendum is "not a separatist movement and is never in contravention of any law whatsoever."71 Even if the sympathies of most of their members are with independence, therefore, groups like SIRA in fact call for a choice between reaffirmation, re-negotiation, or cancellation of the political contract between the Acehnese population and Jakarta.

Of course, an emphasis on human rights abuses can and does coincide with claims for historic sovereignty. Depiction of the brutality of Indonesian rule occupies a central place in GAM discourse, where it is used to illustrate and bolster arguments about the invalidity of Indonesian colonial control. GAM leaders are extremely reluctant to base their arguments on moral grounds alone, however, and are generally adamant that the successor state principle remains central. ${ }^{72}$ In their view, complaints focused on economic exploitation and military repression constitute an insufficient foundation for an appeal for independent statehood. This is because both problems are, at least in theory, amenable to solutions within the framework of the Indonesian state. One GAM spokesperson told the author that "If we just based our claims on human rights, then the Indonesian government could offer to resolve the human rights abuses. That would be the end of it. How could we establish an independent Aceh like that?"73

This view accurately reflects the existing international consensus on selfdetermination. Dragadze notes that an argument for independence based on the loss of a moral right to rule " ... does not fit easily into the coveted UN schemata based as they are not on morality but on the legal principles of territorial sovereignty and the indivisibility of sovereign states." 74 Even so, there are indications that a change is also taking place within GAM. After the upsurge of pro-referendum activity in Aceh in 1999, this organization shifted its position; where before it had rejected the proposal for a referendum (why have a referendum if Aceh had always been an independent state?), now it gave qualified support to such a proposition, so long as the referendum was conducted by the United Nations. ${ }^{75}$

\footnotetext{
71 These quotations are from Muhammad Nazar, "Satu Tahun Perjuangan Damai Referendum Aceh, Menuju Perdamaian dan Penyelesaian Menyeluruh," speech delivered at the Baiturrahman Mosque, Banda Aceh, February 4, 2000.

72 Interviews conducted in Banda Aceh, January- February 2001.

73 Interview with Nashiruddin bin Ahmad, GAM representative on the Komite Bersama Modalitas Keamanan (Joint Committee for Security Modalities), the body established in mid-2000 to oversee the ceasefire between GAM and the Indonesian security forces. Interview January 30, 2001.

74 Dragadze, "Self-determination," p. 347.

75 See for example, "Exiled Aceh Leader Wants UN To Hold Referendum," Associated Press, December 2, 1999.
} 


\section{Global Civil Society and the Search for Alternatives}

Another way in which the impact of globalization and the changing tenor of international relations has been felt in Aceh has been through the reach of global civil society into the territory. As noted above, many authors have argued that the new transnational networks of civil society have begun to play an important role in bypassing and subverting national boundaries, even in pointing the way to a postWestphalian global order that transcends state sovereignty. In Hardt and Negri's phrase, organizations like NGOs may collectively be understood as a global civil society, "channeling the needs and desires of the multitude within the functioning of global power structures." ${ }^{76}$ Certainly, the major transnational human rights NGOs, like Amnesty International and Human Rights Watch, have played an important role in the Aceh conflict, with their reports on human rights abuses regularly translated into Indonesian and circulated widely in the territory. The symbolic power of such organizations has been demonstrated in recent times when Indonesian military spokespersons have sometimes taken to citing Human Rights Watch reports on abuses by GAM in order to bolster their own claims that military action is necessary to uphold law and order in Aceh. ${ }^{77}$ Lobbying by such bodies (as well as by groups formed by the Acehnese diaspora, like the US-based International Forum for Aceh) has garnered some attention for the Acehnese cause in important foreign policy-making institutions, such as the US Congress.

The most important sign of the influence of global civil society in Aceh, however, has been the rapid growth of local NGOs, which began in the early 1990s and accelerated after the end of the Suharto regime. According to one account, there were more than two hundred NGOs in the territory by mid-2000, with many of the newer organizations having an explicit human rights focus. ${ }^{78}$ While it is true that these NGOs responded to local conditions and were created and staffed by local activists, the growth of NGOs in Aceh cannot be understood purely by reference to the Indonesian, let alone the Acehnese, context. Such bodies have been strongly influenced by a multiplicity of linkages with major international funding agencies. Some of these linkages are direct, while others connect via major Jakarta-based NGOs and networks; ultimately their funding derives from international sources. Especially in the years after Suharto's fall, Acehnese human rights, humanitarian, women's, and other NGOs enjoyed a boom in international support, as part of the general increase in "democracy aid" for Indonesia's civil society. The Acehnese NGO sector became a partial check on the activities of the Indonesian state, especially by documenting, publicizing, and criticizing military abuses (such that military officers privately refer to the major NGOs as being part of the GAM "clandestine front"). Their efforts to expose and publicize these abuses were facilitated by the greater media freedom established in the territory after the end of the New Order regime. At the same time, such organizations provided an alternative to the nationalist pole represented by GAM. Although many participants in the local NGO networks privately sympathize with the independence cause, officially these organizations have nothing to say on the question of sovereignty,

\footnotetext{
${ }^{76} \mathrm{Hardt}$ and Negri, Empire, p. 311.

77 See for example, "Dunia Pantau Aksi Kekerasan di Aceh," Serambi Indonesia, June 8, 2001.

78 Tabrani Yunis, Kelahiran dan Perkembangan LSM di Aceh, paper presented to seminar on "Wawasan Tentang LSM Indonesia: Sejarah, Perkembangan, Serta Prospeknya," Jakarta, August 2000, p. 10.
} 
and some have been critical of GAM methods. Indeed, the same international context which has so shaped GAM's claims has prevented Acehnese NGOs from demanding independence. Their reliance on large international donors has obstructed expressions of sympathy for GAM, as such expressions would result in immediate termination of grants. ${ }^{79}$

The emergence of this civil society fueled a search for alternatives between the two contested sovereignties of GAM and the Indonesian state, even if such alternatives have thus far been vaguely formulated. From early in the post-Suharto period, some participants in local NGOs promoted a peace process as a means to create a breathing space between these two apparently irreconcilable nationalisms, a space from which new political possibilities for Aceh could be imagined..$^{80}$ In early 2000, negotiations did begin between the two sides, resulting in a "humanitarian pause" that temporarily suspended hostilities between GAM and the Indonesian security forces from June 2000. Although this process was initiated by Indonesia's President Abdurrahman Wahid and was negotiated between GAM and the Indonesian government, it may in some respects be understood as a project of global civil society. This was most obviously because of the role played by the Henry Dunant Centre for Humanitarian Dialogue, a Geneva-based NGO that acted as the principal mediator during the process, facilitating high-level negotiations in Geneva, establishing an office for ongoing dialogue in Banda Aceh and establishing a set of committees to oversee and monitor the Pause. A broad range of foreign government agencies, transnational NGOs, UN organizations, and local, but globally connected, NGOs swung in behind the peace process. They provided funding, as well as infrastructural and personnel support, for the various monitoring and other committees established under the Pause. In addition, they offered humanitarian assistance for victims of violence and aid for rebuilding shattered communities, intensified human rights monitoring, encouraged broad-based civil society participation in the process, and provided many other forms of support.

Despite a promising beginning and early optimism, by early 2001 the peace process was in disarray. Violence had resumed, reaching its worst level since at least the early 1990s. Many major international humanitarian and other agencies were pulling out of the province. In July 2001, Indonesian security forces registered their disdain for the process by arresting all the main Banda Aceh-based GAM negotiators. A detailed examination of the reasons for the failure of the process cannot be attempted here, although both parties share some blame. ${ }^{81}$ GAM attempted to take advantage of the Pause by consolidating its de facto political control over much of rural Aceh and expanding its armed forces. At least some units affiliated with the organization also continued to attack Indonesian military forces and participate in extortion and similar actions. The more serious obstacle to the peace process, however, was the inability of Indonesia's central government to assert authority over its security forces and prevent them from taking offensive action against GAM and, often, the civilian population. The

\footnotetext{
${ }^{79}$ Some funding agencies have anxiously sent observers to NGO workshops they support in Aceh to ensure that no support is given to the secessionist cause. My thanks to Marcus Mietzner for this point.

${ }^{80}$ Interview with Otto Syamsuddin Ishak, June 1999.

81 For one attempt at detailed assessment of the humanitarian pause, see the second half of Edward Aspinall, "Aceh, self-determination and the international community," paper presented to "Autonomy and Disintegration in Indonesia" conference, La Trobe University, Melbourne, July 7-8, 2001.
} 
drawn-out crisis in Abdurrahman Wahid's government, which coincided with the early stages of the peace process, exacerbated the problem. Senior officers became increasingly openly disdainful of the very idea of a peace process involving "separatists," and security operations were initiated ever more openly, and brutally.

Behind such immediate causes of the breakdown lay deep differences in how the two sides perceived the process, and their continuing irreconcilable positions on sovereignty. While GAM negotiators always made clear that their goal was Acehnese independence, Indonesian negotiators, as well as government and military spokespeople, were equally adamant that talks must remain "within the framework of the unitary state." From the start, concerns were expressed from deep within the Indonesian political and military establishment that even entering into negotiations with GAM in a foreign country and with foreign, even if non-governmental, mediation might be interpreted as tantamount to recognition of equal sovereignty. At every step of the process, Indonesian officials made it clear that their primary concern was to avoid "internationalizing" the Aceh issue and making symbolic concessions on sovereignty. ${ }^{82}$ GAM spokespersons, on the other hand, always argued in favor of greater involvement by the international community, especially the UN, in the peace process, viewing this as a crucial step toward achieving long overdue international recognition of Acehnese demands. ${ }^{83}$

\section{Conclusion}

Acehnese nationalism cannot be viewed as a movement constituted and structured merely in response to domestic conditions. Its character has also been formed, in quite fundamental ways, through a process of interaction with the international system. Precisely because nationalist movements, especially secessionist ones, aspire to membership in the international community of nation-states, international doctrines and norms exercise a deep influence on them. We might say that nationalist movements are Janus-faced not only because they look back to a golden past and forward to a glorious future, as Nairn suggests, but also because they look both inward, toward the collectivity that comprises the nation, and outward, toward the community of nations which they aspire to join. 84

Acehnese nationalists have taken particular care to craft their claims for independent statehood so that they would fit inside the dominant international discourse on self-determination and national sovereignty. Sensitivity to international norms is one factor that accounts for the secessionists' emphasis on Aceh's precolonial history and their denial of Aceh's historical incorporation as part of Indonesia. This reliance on the concept of historic sovereignty has in turn shaped other elements of the Acehnese nationalist agenda, including the form of the future state to be adopted.

\footnotetext{
82 For one such example, see "Mimpi, Libatkan Negara Ketiga Selesaikan Aceh," Serambi Indonesia, November 28, 2001.

83 See for example, "GAM Desak Tim Internasional ke Aceh," Kompas, June 7, 2001; "Soal Aceh, Pemerintah Tetap Utamakan Dialog," Media Indonesia, August 18, 2001.

84 Tom Nairn, The Break-up of Britain: Crisis and Neo-Nationalism (London: New Left Books, 1977).
} 
Over the last decade, the growth of international human rights discourse and associated growth of global civil society has also exerted an influence on Acehnese nationalism. Some Acehnese groups, especially those consisting of younger activists, while retaining the basic goal of independence, have responded by foregrounding rights-based arguments for self-determination. By doing so, they changed the goal of independence from a non-negotiable demand for restitution of historic sovereignty, based on the principle of rectificatory justice, to something which was more contingent and contextual, leaving open the possibility of negotiation, compromise, and pursuit of a resolution by democratic means.

Such a possibility was also suggested by the agents of global civil society as they intervened in the Aceh conflict, standing aside from the two contested sovereignties of GAM and the Indonesian state, hinting at possibilities for a world where statesovereignty was no longer the supreme organizing principle. When the peace process failed, however, that failure unavoidably suggested that state sovereignty in its classic form retained its supremacy and emotive power. The suffering of the Acehnese population in the years since 1998 also bears testimony to the devastation which may be wrought when two of sovereignty's offspring-the principles of national selfdetermination and the territorial integrity of nation-states-come into conflict. 